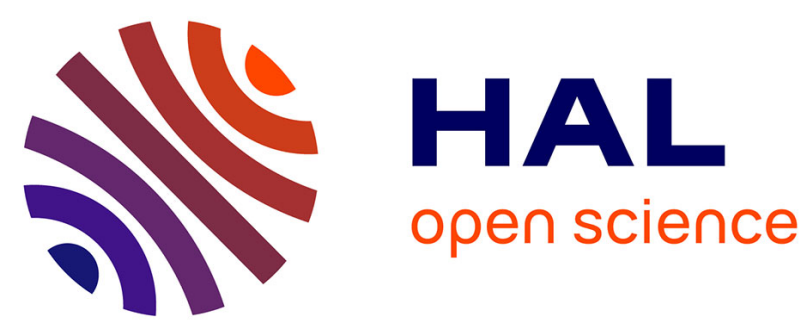

\title{
Lean Manufacturing and Environmental Performance - Exploring the Impact and Relationship
}

Simon Peter Nadeem, Jose Arturo Garza-Reyes, Sin-Ching Leung, Anass

Cherrafi, Anthony I. Anosike, Ming K. Lim

\section{- To cite this version:}

Simon Peter Nadeem, Jose Arturo Garza-Reyes, Sin-Ching Leung, Anass Cherrafi, Anthony I. Anosike, et al.. Lean Manufacturing and Environmental Performance - Exploring the Impact and Relationship. IFIP International Conference on Advances in Production Management Systems (APMS), Sep 2017, Hamburg, Germany. pp.331-340, 10.1007/978-3-319-66926-7_38 . hal-01707298

\section{HAL Id: hal-01707298 \\ https://hal.inria.fr/hal-01707298}

Submitted on 12 Feb 2018

HAL is a multi-disciplinary open access archive for the deposit and dissemination of scientific research documents, whether they are published or not. The documents may come from teaching and research institutions in France or abroad, or from public or private research centers.
L'archive ouverte pluridisciplinaire HAL, est destinée au dépôt et à la diffusion de documents scientifiques de niveau recherche, publiés ou non, émanant des établissements d'enseignement et de recherche français ou étrangers, des laboratoires publics ou privés.

\section{(c)(1)}

Distributed under a Creative Commons Attribution| 4.0 International License 


\title{
Lean Manufacturing and Environmental Performance - Exploring the Impact and Relationship
}

\author{
Simon Peter Nadeem $\rrbracket^{1}$, Jose Arturo Garza-Reyes ${ }^{1}$, Sin-Ching Leung ${ }^{2}$, \\ Anass Cherrafi ${ }^{3}$, Anthony I. Anosike ${ }^{1}$, and Ming K. Lim ${ }^{4}$ \\ ${ }^{1}$ Centre for Supply Chain Improvement, University of Derby, Derby, UK \\ S.Nadeem@derby.ac.uk; J.Reyes@derby.ac.uk; \\ A. Anosikedderby . ac.uk \\ ${ }^{2}$ PAL Surface Treatment System Ltd., Hong Kong \\ sincleung2-c@my. cityu. edu.hk \\ ${ }^{3}$ Cadi Ayyad University, Marrakech, Morocco \\ anass.charrafieced.uca.ma \\ ${ }^{4}$ Centre for Business in Society, Coventry University, Coventry, UK \\ Ming. Lim@coventry.ac.uk
}

\begin{abstract}
The relationship between Lean Manufacturing and Environmental Performance has attracted much debate but at the same time lack of empirical evidence leaves haphazard opinions on this matter. The objective of this paper is therefore to provide some insight into the impact of Lean Manufacturing on Environmental Performance and the existing relationship of these two concepts. Four semi-structured interviews with industrial and academic experts provided a solid ground to suggest that the relationship does exist, despite the fact that these two concepts were developed independently from each other. Being the exploratory nature of this study and its purpose to ignite further research, it does not employ a quantitative approach. The results of this study can help managers to better understand and concurrently tackle both the economic and environmental challenges faced by their organizations.
\end{abstract}

Keywords: Lean Manufacturing, Environmental Performance, Value, Wastes

\section{Introduction}

In the presence of growing competition, depleting resources, rising costs, and escalated concerns for the environment, businesses have been pushed to explore new ways to maximize efficiency and effectiveness by developing new philosophies/ methods to improve production/ services while at the same time minimizing the negative impact of the operations on the environment. After the World War II, Toyota was faced with fierce competition by its US rival car manufacturers [1], and in order to keep themselves operational in excelling manner, it developed the Lean Manufacturing (hereafter referred as LM) framework [2]. Since then, the concept has been widely appraised and adopted by a wide range of companies and industries around the world $[1,3]$ to improve the competitive edge [4] for their businesses.

There are numerous approaches that constitute the structure of a lean system, e.g. Total Quality Management, Just-in-Time [5], Kanban, and Jidoka [6]. Lean helps to identify and eliminate non-value added activities and optimize performance [7]. Hence, organizations implement lean in order to increase production flexibility and improve product quality while keeping costs low [8]. 
orcid.org/0000-0002-0571-0744

For the lean theory, wastes refer to any activity that do not add value [7], whereas from an environmental perspective waste refers to the unnecessary consumption of resources and/or release of harmful substances into the environment, creating a negative effect on this and human health [9]. For example, waste of overproduction - producing without demand - is waste of resources/ energy. Thus, an organization implementing lean is not only reducing cost, but is contributing to resource preservation.

The attention to the relationship between lean and green has gained momentum recently [1]. However, the academic literature examining the impact of LM on environmental (also known as 'green') performance still remains in early stages [1,10]. Thus, the aim of this article is to investigate the relationship and impact of LM on Environmental Performance and the existing relationship of these two concepts. In this way, this article mainly focuses on the meaning of the green concept waste so as to investigate the relationship between LM and environment. Moreover, only the original seven manufacturing wastes, as defined by Toyota, are considered in this study.

The study in this article provides a brief overview of the literature to explore the relationship between seven wastes identified under the lean philosophy and environmental performance (hereafter referred as EP). Each of the manufacturing wastes that lean attempts to reduce is somewhat associated with EP. Hence, attention is focused on if and how lean creates more environment friendly production processes.

\section{Theoretical Background}

\subsection{Lean Manufacturing}

The development of LM dates back to as far as 1927, when the embryonic idea was laid out by Henry Ford [11]. However, its more rigorous development has been associated to the Toyota Production System [1]. John F. Krafcik was the first to coin the term 'Lean Production' [7,12]. Lean's unique blend of focusing on reducing waste and maximizing value attracted the attention of business practitioners to adapt this approach [13] and has hence gained tremendous magnetism in the US since the 1960s [11]. Scholars also believe that Lean is not just related to manufacturing as it is mostly known for, but is a business culture [14]. The Toyota's LM system identifies 7 types of wastes, and an addition to those seven wastes was made by Jeffery K. Liker [15]. These wastes are in the area of; (1) Overproduction, (2) Waiting (time on hand), (3) Unnecessary transport, (4) Over processing or incorrect processing, (5) Excess inventory, (6) Unnecessary movement, (7) Defects, (8) Unused employee creativity.

Despite its mass appraisal/ adoption in manufacturing and service industries, and by academics, there is a lack of agreement for a common definition of the concept $[11,16]$. Thus, it becomes hard to define its overall goals [17]. However, LM is a major contributor to revolutionize businesses in their pursuit of doing more with less, while preserving value [14]. At the core of Lean, waste is defined as any non-value adding activity [18], and the focus is to promote a continuous improvement culture [14] and customer value enhancement by eliminating waste [7].

\subsection{Metrics of Environmental Performance}

The World Economic Forum (WEF) developed the Pilot EP Index in collaboration with Yale Center for Environmental Law and Policy, and Center for International Earth Science Information Network of Columbia University [19]; utilizing 4 dimen- 
sions (see Table 1) to measure the EP of any institution. The Department for Environment, Food and Rural Affairs (DEFRA) [20] in the UK also used similar measuring dimensions (see Table 1). The Global Environmental Management Initiative (GEMI) [21] in the US identified a longer list of measures being used by companies surveyed by them. This list does covers the $8^{\text {th }}$ waste of Lean identified by Liker [15], however the dimensions mentioned revolve around the four core aspects identified by WEF and DEFRA (see Table 1).

Table 1. Dimensions used by different organization to measure EP.

\begin{tabular}{|c|c|c|c|}
\hline & WEF & DEFRA & GEMI \\
\hline \multirow{16}{*}{ 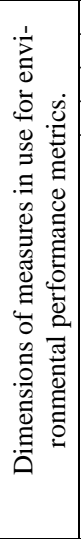 } & Air Quality & Emission to Air & Permitted Air Emission \\
\hline & Water Quality & Emission to Water & Amount of water used \\
\hline & Land Protection & Emission to Land & Quantity of toxic chemical released \\
\hline & Climate change & Resource use & Amount of hazardous waste generated \\
\hline & & & Number of recordable injuries/illnesses \\
\hline & & & Number of lost workday cases \\
\hline & & & Number of notices of violation \\
\hline & & & Type/volume of non-regulated materials recycled \\
\hline & & & Type/volume of non-regulated materials disposed \\
\hline & & & Amount of dollar fines \\
\hline & & & Number/ type of reportable releases \\
\hline & & & Amount/ type of fuel used \\
\hline & & & Total annual EHS operating costs \\
\hline & & & Number of regulatory inspections \\
\hline & & & Ozone depleting substance use \\
\hline & & & Total annual EHS capital costs \\
\hline
\end{tabular}

Overall, it would be correct to say that the four common dimensions of air, water, climate, and land, mentioned in Table 1 are at the core of the measurement of EP [22] in any organization. However, it is important to understand that the choice of measures would depend directly on the type of industry/ organization and their activity. Some indicators are common, as mentioned above, whereas others might be unique to a specific industry [21]. Therefore this research takes the basic general overview of EP measures and explore its relationship with LM.

\subsection{The Interaction between Lean and Environment}

There is both positive and negative opinions on the matter of the interactions between LM and Green under the realization that the core focuses of Lean and Sustainability are different [23]. However, scholars do believe that the LM and Green approaches are conceptually similar [24] and that Lean's focus on the reduction of waste, in itself, proves its positive environmental effect [23]. Therefore, the alignment of LM and Green seems natural [25]. Consequently, the term Green Lean has emerged [26]. While it is true that LM does seem to have a direct relationship with EP, it is also evident that the environmental aspect has not been the core reason for the development of LM [27, 28], and that initiatives of EP (Green) and LM have been developed independently from each other [29].

Regardless of the core reasons for the development of LM and Green, and the fact the two cannot be perfectly combined [25], scholars agree that there are synergetic opportunities between lean and sustainability [23] and that they are concurrent and 
can effectively work together [23]. The U.S. Environmental Protection Agency [8] published a report referring to a strong linkage between LM and its impact on the environment. There is a shortage of in-depth research on their correlation and output [1], as well as the empirical evidence is sparse [10]. As a result of that, this paper further examines this with empirical evidence.

It is evident that the implementation of LM is not with concerns for the environment but is for business improvement. Scholars did raise concerns regarding the cost of improving EP initiatives being high may undermine the economic sustainability of the business [30]. But authors do agree that LM, alongside improving industrial performance, also contributes to environment performance improvement [10, 31].

Figure 1 below portrays the authors' understanding in light of the published articles and empirical evidence explored in this study, about the relationship between LM's 7 areas of waste and the 4 core dimensions to measure EP. The $8^{\text {th }}$ waste of lean, unused employee creativity, has not been included as it's not directly linked with EP, although indirectly it does play a role in assessment and policy development for EP.

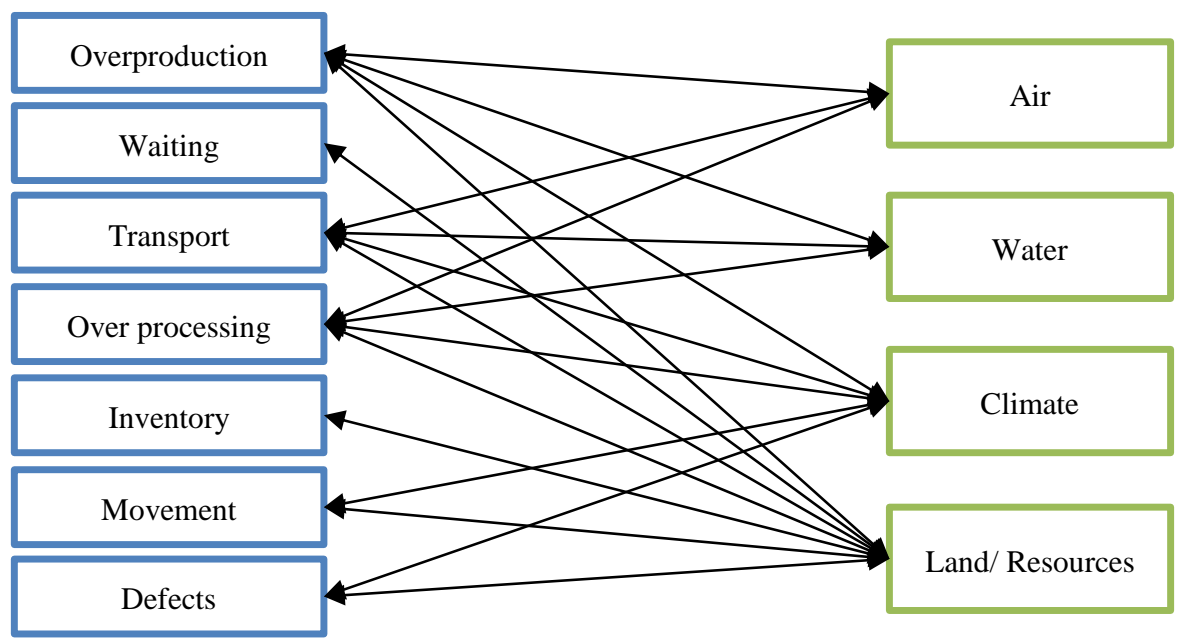

Fig. 1. Relationship between Lean's 7 wastes and Environmental Performance Measures

\section{Research Method}

The scope of this paper is to explore the impact of LM on EP and their relationship. For this purpose, empirical evidence and opinions were collected from industrial leaders/ practitioners from China and Hong Kong. Four interviewees were carefully selected to represent a diverse range of industrial backgrounds/ experience, and were interviewed independently from each other. A brief profile of the research participants is presented in Table 2. Names of the individuals, and their companies, are kept anonymous under a confidentiality agreement.

The interviews were conducted via Skype and were audio recorded. Since all respondents were from different industries, it would be complex to compare their responses but at the same time it does give a good diversified understanding and eliminates bias. 


\subsection{Research Question/ Framework of the Study}

A questionnaire that consisted of 16 open ended questions was developed, with two major dimensions in focus on which the whole of this study hinges:

1. Are Lean and Environmental Performance related?

2. Does lean impact/ improve environmental performance?

Table 2. Research Participants Profile

\begin{tabular}{|c:l:c:c|}
\hline $\begin{array}{c}\text { Partic- } \\
\text { ipant }\end{array}$ & Position & \multicolumn{1}{c|}{$\begin{array}{c}\text { Industry } \\
\text { Affiliation }\end{array}$} & \multicolumn{1}{c|}{ Experience } \\
\hdashline A & $\begin{array}{l}\text { Project } \\
\text { Manager }\end{array}$ & Food & Over 8 years of experience in implementing LM principles in \\
production/ processing industry
\end{tabular}

\section{$4 \quad$ Results and Analysis}

The interviews helped to collect primary data from industry leaders/ practitioners. The responses provided a glimpse of diverse opinions on the matter and yet uniformity to some extent as well. The collected results are summarized in four dimensions (see Figure 2) highlighting the core essence of this study, and are discussed below.

\subsection{Are Lean and Environmental Performance Related?}

The respondents' opinion leads to an inconclusive estimation about the relationship between LM and $\mathrm{EP}$, except for one respondent whose opinion was based upon implementation perspective, rather than their rational nature. The reason to base their inconclusive opinion was the very core reasons for the development of these concepts.

The respondents believed that the development of both concepts is independent and irrespective of each other and with very different focuses, one being on production/ service optimization in a cost ef-

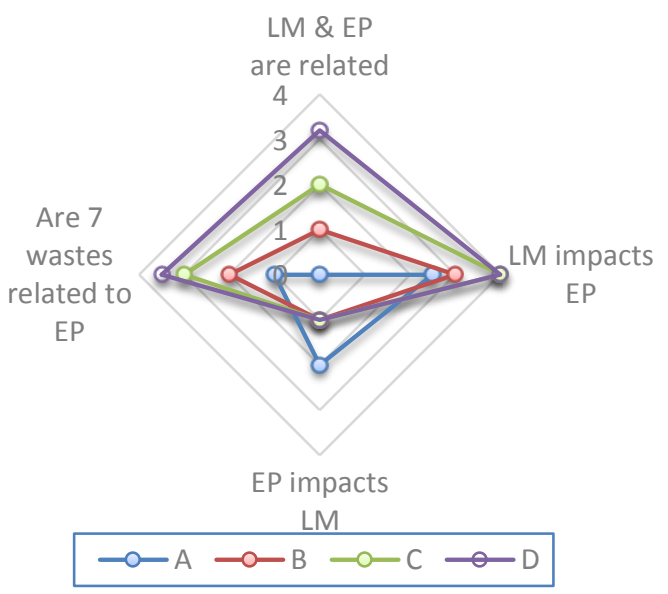

Fig. 2. Summarization of results in four Dimensions fective manner and the other being on environmental improvement, with a much broader prospective than just the economic benefit. However, they do believe that in the practical output they do seem to relate, and this is discussed further.

\subsection{Does Lean Impact/ Improve Environmental Performance?}

All the respondents acknowledge the positive contribution of LM towards EP. Some of the views are as follows:

- Implementing lean does foster EP. 
- EP improvement is an added/ bonus feature of LM.

- Some examples shared by respondents are:

- Usage of plastic pallet instead of wooden one was adopted under lean due to short lifecycle and less durability of wooden pallet. This did improve EP by utilizing reusable material (plastic) and preserving resources by not using wood and not burning it at the end of life cycle.

o Reduction in transportation of material has a dual effect. Positive effect by optimizing the operation time, reducing cost, as well as reducing emissions. But at the same time, lower inventory requires more frequent deliveries, thus an increase in emission, but it does balance itself by decreased/delayed resource extraction, and no stagnation of material in storage.

o The food industry greatly benefits from LM, as by adopting JIT principles it minimize the obsolescence and wastage contributing to environmental pollutants.

○ Another respondent highlighted the indirect impact on EP through the utilization of Kanban systems to optimize information flow and reduce the usage of energy by avoiding over processing or incorrect processing.

○ With reference to one of the participants' responses, the design of assembly/ production line affects efficiency. In general, a U-shaped assembly line system is given appraisal by participants, which is also highlighted by scholars [32]. It can improve efficiency by reducing motion within the processes, increase labor productivity by using less people to do the same work - so as to reduce the usage of natural resources and loss of other potential usage.

$\circ$ By applying the TQM and Lean approaches, the possibility of defective product is minimized to the maximum possible extent, thus resulting in the preservation of natural resources and energy utilized for production.

In general, the environmental impacts of allocation of inventory, volume of production and defects have a strong linkage to the lean strategy.

\subsection{Does Environmental Performance Impacts Lean?}

The respondents tended to have negative opinion about EP impacting LM. Based on their opinion, businesses are more concerned with economic performance and would only (or mostly) act to improve EP if the regulatory authorities require so or otherwise if they come implicit in the management philosophies such as in the case of LM.

One respondent described implementation of lean in relation to the cost charged by the government, for the amount of polluted water released from their production facility and the need to keep it low. Therefore, the regulatory institutions with the EP goals of reducing polluted water and by placing cost on its disposal, resulted in the company adopting Lean. But such scenarios may not be very common. Mostly its other way around, where business improve EP to increase their market share or that EP come inherent within the optimization of operations through implementation of Lean.

4.4 Are 7 Wastes of Lean Related to Dimension of Environmental Performance? Participants believe in the synergies between LM and EP but there are mixed reasoning on the linkage between the seven wastes of Lean and the four dimensions of EP.

Participants reason that LM might not always contribute to EP, as is the case with frequent deliveries, discussed above. Also, in the food industry and other operational 
orcid.org/0000-0002-0571-0744

facilities, water and other chemical fluids are used for cleaning equipment, which has to be done at least daily and sometimes several times a day. Thus, LM processes requiring frequent cleanup result in the release of more polluted liquid waste. Another participant argued that by doing so, process efficiency/ accuracy is achieved which indirectly links to EP.

Finally, all the respondents suggested that LM has no relationship with toxic pollutants. If the regulatory authorities do not allow their usage or cap it to specific limit, industries will have to follow the guidelines.

\section{Conclusion}

This article provides an overview of the conceptual understanding of LM, EP, and their relationship. The qualitative analysis of empirical data collected through in depth interviews has provided understanding from the practitioners' point of view. Based on the survey results, it would be correct to say that both the LM and EP are interlinked to some extent but their development and implementations are done with totally different focuses. However given the dual nature of LM, it might be best for institutions promoting EP among industries to highlight LM as an enabler/ approach in order to be more appealing and motivating to businesses. Due to the limitation of small sample size of interviewees, the study results cannot be generalized. Further research is highly recommended to expand the understanding and strengthen the implications of these two concepts to each other.

\section{References}

1. Garza-Reyes JA. Lean and green - a systematic review of the state of the art literature. Journal of Cleaner Production. 2015; 102: p. 18-29.

2. Herron C, Hicks. The transfer of selected lean manufacturing techniques from Japanese automotive manufacturing into general manufacturing (UK) through change agents. Robotics and Computer-Integrated Manufacturing. 2008; 24(4): p. 524-531.

3. Garza-Reyes JA, Parker HS, Oraifige I, Soriano-Meier H, Harmanto D. An empiricalexploratory study of the status of lean manufacturing in India. International Journal of Business Excellence. 2012; 5(4): p. 395-412.

4. Hines P, Holweg M, Rich N. Learning to evolve: A review of contemporary lean thinking. International Journal of Operations \& Production Management. 2004; 24(10): p. 9941011.

5. Shah R, Ward PT. Lean manufacturing: context, practice bundles, and performance. Journal of Operations Management. 2003; 21: p. 129-149.

6. Slack N, Brandon-Jones A, Johnston R. Operations Management. 8th ed. Harlow: Pearson; 2016.

7. Womack JP, Jones DT, Roos D, Carpenter DS. The Machine that Changed the World New York: Simon \& Schuster; 1990.

8. U.S. Environmental Protection Agency. Lean Manufacturing and the Environment: Research on Advanced Manufacturing Systems and the Environment and Recommendations for Leveraging Better Environmental Performance. USA:; 2003.

9. U.S. Environmental Protection Agency. The Lean and Environment Toolkit: United States Environmental Protection Agency; 2007.

10. King AA, Lenox MJ. Lean and Green? An Empirical examiniation of the relationship between Lean Production and Environmental Performance. Porduciton and Operations Management. 2001; 10(3): p. 224-236. 
11. Shah R, Ward T. Defining and developing measures of lean production. Journal of Operations Management. 2007; 25: p. 785-805.

12. Krafcik JF. Triumph of the Lean Production System. MIT Sloan Management Review. 1988; 30(1).

13. Jadhav JR, Mantha S, Rane SB. Exploring barriers in lean implementation. International Journal of Lean Six Sigma. 2014; 5(2): p. 122-148.

14. Pampanelli AB, Found P, Bernardes AM. A Lean \& Green Model for a production cell. Journal of Cleaner Production. 2014; 85: p. 19-30.

15. Liker JK. The Toyota Way New York: McGraw-Hill ; 2004.

16. Pettersen J. Defining lean production: some conceptual and practical issues. The TQM Journal. 2009; 21(2): p. 127-142.

17. Andersson R, Eriksson H, Torstensson H. Similarities and differences between TWM, six sigma and lean. The TQM Magazine. 2006; 18(3): p. 282-296.

18. Omogbai O, Salonitis K. A lean assessment tool based on systems dynamics. Procedia CIRP. 2016; 50: p. 106-111.

19. Yale Center for Environmental Law and Policy. Pilot Environmental Performance Index.; 2002.

20. Department for Environment, Food and Rural Affairs. Environmental Key Performance Indicators. London:; 2006.

21. Global Environmental Management Initiative. Measuring Environmental Performance: A Primer and Survey of Metrics in Use. Washington D.C.:; 1998.

22. Bandehnezhad M, Zailani S, Fernando Y. An empirical study on the contribution of lean practices to environmental performance of the manufacturing firms in northern region of Malaysia. International Journal of Value Chain Management. 2012; 6(2): p. 144-168.

23. Leon HCM, Calvo-Amodio J. Towards lean for sustainability: Understanding the interrelationships between lean and sustainability from a systems thinking perspective. Journal of Cleaner Production. 2017; 142: p. 4384-4402.

24. Torielli RM, Abrahams RA, Smillie RW, Voigt RC. Using lean methodologies for economically and environmentally sustainable foundries. In The 69th World Foundry Congress; 2010; Hangzhou, China: China Foundry. p. 74-88.

25. Garza-Reyes JA. Green lean and the need for Six Sigma. International Journal of Lean Six Sigma. 2015; 6(3): p. 226-248.

26. Garza-Reyes, J.A., Winck Jacques, G., Lim, M.K., Kumar, V., Rocha-Lona, L. Lean and green - synergies, differences, limitations, and the need for Six Sigma. in B. Grabot et al. (Eds.): International Conference on Advances in Production Management Systems (APMS) 2014, Part II, IFIP AICT 439, Ajaccio, France, 20-24 September, Springer.

27. Azevedo S, Carvalho H, Duarte S. Influence of Green and Lean Upstream Supply Chain Management Practices on Business Sustainability. IEEE Transactions on Engineering Management. 2012; 59(4): p. 753-765.

28. Durate S, Cruz-Machado V. Modelling lean and green: a review from business models. International Journal of Lean Six Sigma. 2013; 4(3): p. 228-250.

29. Dhingra R, Kress R, Upreti G. Does Lean mean Green? Journal of Cleaner Production. 2014; 85: p. 1-7.

30. Florida R. Lean and Green: The Move to Environmentally Conscious Manufacturing. California Management Review. 1996; 39(1): p. 80-105.

31. Corbett J, Klassen RD. Extending the Horizons: Environmental Excellence as Key to Improving Operations. Manufacturing \& Service Operations Management. 2006; 8(1): p. $5-22$.

32. Sirovetnukul R, Chutima P. The Impact of Walking Time on U-shaped Assembly Line Worker Allocation Problems. Engineering Journal. 2010; 14(2): p. 53-78. 